Maisaroh \& Ati Sumiati: Tantangan dan Peluang Perbankan Syariah Dalam Pengembangan UKM Untuk Memperkuat Kesejahteraan Umata

\title{
TANTANGAN DAN PELUANG PERBANKAN SYARIAH DALAM PENGEMBANGAN USAHA KECIL DAN MENENGAH UNTUK MEMPERKUAT KESEJAHTERAAN UMAT
}

\author{
Maisaroh* \\ Ati Sumiati*
}

\begin{abstract}
Islamic Banking of Indonesia lately grows so rapidly. The function of Islamic banking is as intermediary institution between the excess money parties (depositor) with the lacking money parties (borrower) by using a system of Islamic sharia. The operational purpose of Islamic banking is to participate actively in development process of social and economic life of the community in managing all assets for social welfare. In other side, the growth of small -medium enterprises in Indonesia are also very fast. These types of institutions are identified and proved to be the savior of the economic crisis in Indonesia. But, small and medium enterprises have difficulty constraints of capital and human resources that make these institutions are difficult to thrive. According to the operational purpose, Islamic banking and smallmedium enterprises can be partners of mutual benefit. Both parties should build up a quality partnership with optimizing the role of empowerment and facilitation of the Islamic banking to small-medium enterprises using the principles of relationship, togetherness, and humanitarian. Coupled with improving the quality of human resources, services, and partnership, then the partnership is expected not only profitable for both parties, but also more broadly is expected to create social welfare for community.
\end{abstract}

Keywords: Islamic Banking, Small and Medium Enterprises, Social Welfare, Empowerment

\section{PENDAHULUAN}

Sejak muncul dan berkembang pada awal tahun 1990, yang ditandai berdirinya Bank Muamalat sebagai pelopor, bank syariah sampai sekarang terus mengalami perkembangan signifikan. Perkembangan bank syariah ini sedemikian pesatnya sehingga saat ini di Indonesia sudah tbanyak berdiri bank syariah. Bahkan hampir semua

\footnotetext{
* Maisaroh \& Ati Sumiati. Dosen Fakultas Ekonomi Universitas Negeri Jakarta.
}

bank konvensional di Indonesia memiliki unit syariah dalam proses kegiatan usahanya. Selain bank syariah, ditingkat wilayah yang lebih kecil juga banyak bermunculan bank perkreditan rakyat syariah (BPRS) dan baitul maal wa tamwil (BMT) sebagai lembaga simpan pinjam berbasis syariah dengan wilayah operasinal hanya berada di daerah dimana lembaga tersebut berada.

Perkembangan ini tentu saja sangat menggembirakan. Paling tidak 
jika dilihat dari dua hal. Pertama, di tengah terpuruknya banyak bank umum konvensional akibat tekanan krisis moneter, bank syariah justru berkembang dengan pesat bahkan mampu menunjukan eksistensinya sebagai sebuah lembaga keuangan yang handal. Kedua, berkembangnya bank syariah semakin memberikan banyak pelayanan perbankan altenatif bagi masyarakat terutama bagi masyarakat yang membutuhkan semacam "kenyamanan psikologis" dalam menggunakan jasa perbankan.

Perkembangan di atas dipengaruhi oleh beberapa faktor. Pertama, banyak bank umum konvensional yang menggunakan sistem bunga sebagai dasar operasinya mengalami ketidakseimbangan laporan keuangannya, atau antara transaksi tabungan dan pembiayaan yang dilakukan perusahaan. Kondisi ini membawa perusahaan pada tingkat kerugian yang terus menerus, bahkan pada kondisi yang paling buruk banyak bank yang dilikuidasi karena sudah tidak mampu beroperasi lagi. Sementara di sisi lain bank syariah yang menggunakan sistem bagi hasil sebagai dasar operasinya, yang sekaligus sebagai keunggulannya, semakin mantap melangkah dan meraup keuntungan yang selalu meningkat dari waktu ke waktu.

Kedua, ada kecenderungan dari kelompok masyarakat tertentu (Islam), yang mulai berfikir untuk menerapkan pola hidup yang sesuai dengan syariah Islam, begitu juga dalam hal perekonomian. Sehingga ketika bank syariah mulai berkembang dan masyarakat dapat mengakses dengan mudah berbagai fasilitasnya, maka kelompok ini dengan kesadaran sendiri mulai memindahkan transaksi dana (baik menyimpan atau meminjam) dari bank konvensional menuju bank syariah. Ketiga, adanya perhatian yang lebih serius dari Bank Indonesia sebagai pemegang otoritas moneter, dengan dibuktikan oleh diterbitkannya UU untuk landasan operasional bank syariah, dan dibentuknya tim penelitian dan pegembangan bank syariah, yang menjadi pendukung kesuksesan operasional bank syariah.

Dari sisi bisnis, perkembangan bank syariah ini akan membawa dampak yang positif, terutama jika dikaitkan dengan aliran dana yang akan masuk ke rekening bank syariah, karena dengan semakin banyak bank syariah yang berkembang dengan baik, maka kepercayaan dan ketertarikan masyarakat untuk menggunakan jasa layanan bank syariah akan semakin meningkat, dan kondisi ini akan berpengaruh secara langsung pada aliran dana yang semakin meningkat.Ini berarti bahwa ada kenaikan tingkat likuiditas perusahaan. Akan tetapi harus diingat bahwa kondisi likuiditas yang tinggi ini harus bisa menguntungkan perusahaan. Oleh karena itu perusahaan harus mampu menyeimbangkan antara aliran dana masuk (tabungan) dan aliran dana keluar (pembiayaan), sehingga perusahaan mampu menghasilkan laba yang optimal (sistem perekonomian Islam melarang praktek riba, tapi membolehkan kita untuk mencari keuntungan sebanyak-banyaknya). 
Maisaroh \& Ati Sumiati: Tantangan dan Peluang Perbankan Syariah Dalam Pengembangan

Dampak lain yang muncul dari perkembangan bank syariah adalah semakin besarnya tingkat persaingan di pasar, yang berarti setiap perusahaan harus mampu merebut konsumen dan mempertahankam pelanggan setianya agar tidak mengalami kemunduran.

\section{TANTANGAN YANG DIHADAPI BANK SYARIAH \\ Tantangan Produk \\ Pengembangan}

Fungsi bank syariah, seperti bank umum lainnya, adalah sebagai lembaga perantara (intermediasi) antara pihak yang kelebihan uang (pemodal/penabung) dan pihak yang kekurangan modal (peminjam). Yang membedakannya dengan bank umum adalah bank syariah dalam operasionalnya menyediakan jasa/layanan keuangan dengan konsep/sistem syariah Islam yaitu mendasarkan pada sistem bagi hasil dan bukan sistem bunga. Tujuan utama dari setiap ooperasionalnya adalah secara aktif ikut berpartisipasi dalam proses pengembangan sosial ekonomi masyarakat dalam bentuk manajemen aset-asetnya untuk kesejahteraan masyarakat (sosial welfare).

Praktek ideal model pembiayaan syariah harus diarahkan menuju pembiayaan dengan prinsip bagi hasil yang menekankan pola hubungan kemitraan (partnership) antara pihak bank dan nasabah, yang dalam hal ini model pembiyaan musyarakah (kemitraan aktif) dan model pembiyaan mudharabah (kemitraan pasif) menjadi alternatif pembiyaan yang ideal. Dibandingkan dengan akad jual beli, pembiyaan dengan akad bagi hasil ini akan memberikan kemanfaatan yang lebih besar pada seluruh lapisan masyarakat. Meskipun bank syariah saat ini sudah berkembang dengan pesat, akan tetapi lembaga ini ternyata belum mampu untuk berperan secara optimal dalam operasionalnya. Sebagian besar praktek operasional bank syariah di Indonesia saat ini masih menempatkan sebagian besar dananya pada pembiayaan dengan akad jual beli, seperti murabahah, ijarah, salam, dan istisma. Dan mereka menempatkan porsi yang lebih kecil pada pembiayaan musyarakah dan mudharabah.

Praktek bank syariat dengan model pembiayaan akad jual beli sebenarnya bukan praktek yang dilarang oleh syariat Islam. Akan tetapi perlu dicermati bahwa kalau praktek ini tidak dilakukan dengan hati-hati bisa membawa dampak pada pola konsumtif yang berlebihan $\mathrm{di}$ masyarakat, dan yang lebih parah adalah adanya konsentrasi penumpukan kekayaan hanya pada kelompok masyarakat tertentu. Kondisi ini sangat bertentangan dengan tujuan ideal dari operaional bank syariah yaitu untuk membangun kesejahteraan masyarakat. Di samping itu Islam melarang keras budaya konsumtif. Begitu juga Islam melarang adanya penumpukan kekayaan hanya pada kelompok masyarakat tertentu, tetapi kekayaan tersebut harus disebarkan secara merata untuk kesejahteraan seluruh masyarakat. Selain itu praktek pembiayaan dengan akad jual beli 
memiliki potensi yang besar menjadikan perusahaan tergelincir pada praktek pembiayaan dengan sistem bunga.

Alasan klasik yang sering dikemukakan oleh pihak bank yang masih mengalokasikan dananya dalam porsi kecil untuk pembiayaan musyarakah dan mudharabah adalah munculnya agency problem dalam akad pembiayaannya. Seperti kita ketahui bahwa salah satu kelemahan dari model musyarakah dan mudharabah adalah pihak bank tidak punya wewenang untuk ikut campur secara langsung dalam menentukan kebijakan perusahaan, sehingga bank tidak bisa menentukan apalagi mengontrol jumlah keuntungan perusahaan mitra. Beberapa ahli ekonomi syariah mengatakan bahwa ketidakseimbangan manajemen dan kontrol disebut sebagai penyebab utama kurangnya minat bank syariah dalam melaksanakan akad dengan sistem bagi hasil. Sementara perusahaan mitra biasanya tidak mau terbuka terhadap urusan informasi kemajuan perusahaan. Apabila jika dalam akad pembiayaannya tidak dicantumkan secara jelas hak dan kewajiban masing-masing. Faktor inilah yang menjadi kunci munculnya agency problem. Kondisi ini akan semakin parah jika perusahaan mitra tidak bisa dipercaya, atau pihak bank sendiri tidak mempercayai perusahaan mitra secara penuh. Karena potensi munculnya agency problem ini begitu besar, maka bank menganggap bahwa pembiayaan dengan akad musyarakah dan mudharabah merupakan pembiayaan yang beresiko tinggi, sehingga mereka harus berhati-hati dalam melakukan praktek pembiayaan ini. Biasanya mereka hanya akan melakukan pembiayaan dengan akad ini hanya kepada pihak-pihak yang sudah mapan dan dapat dipercaya saja.

Meskipun terjadi kondisi dilematis dalam praktek operasional pembiayaan dengan sistem bagi hasil, praktisi perbankan syariah harus mencari solusi yang baik dalam menangani agency problem di atas, sehingga proses distribusi aset produktif perusahaan tetap dapat dialokasikan untuk pembiayaan musyarakah dan mudharabah. Karena dengan meniadakan atau mengurangi alokasi pembiayaan pada akad ini bukan keputusan yang strategis. Bahkan sebenarnya produk musyarakah dan mudharabah bisa menjadi produk unggulan bank syariah.

\section{Tantangan Pengembangan SDM dan Infrastuktur}

Kepercayaan masyarakat yang mulai meningkat terhadap bank syariah harus diimbangi dengan bukti kinerja yang baik dari lembaga tersebut. Kinerja lembaga bank syariah bisa ditandai dengan meningkatnya rasio kecukupan modal, meningkatkan jumlah pelanggan, serta meningkatnya pelayanan yang diberikan kepada pelanggan.

Salah satu factor yang menentukan peningkatan kinerja lembaga bank adalah dengan ketersediaan SDM dan infrastrauktur pendukung yang berkualitas. SDM yang berkualitas yang dibutuhkan oleh 
Maisaroh \& Ati Sumiati: Tantangan dan Peluang Perbankan Syariah Dalam Pengembangan UKM Untuk Memperkuat Kesejahteraan Umata

bank syariah adalah SDM yang secara keilmuan paham tentang konsep bank syariah dan ekonomi syariah, dan secara psikologis dia memiliki semangat keislaman yang tinggi. SDM yang hanya mengerti tentang ilmu bank syariah dan ekonomi syariah saja, tetapi tidak memiliki semangat keislaman yang tinggi, maka ilmunya bagai tidak ada ruh. Sehingga dalam beraktifitas sehari-hari dia tidak ada rasa memiliki (sense of belonging) dan rasa tanggung jawab (sense of responsibility) terhadap kemajuan bank syariah. Dan sebaliknya SDM yang hanya memiliki semangat keislaman yang tinggi tetapi tidak memiliki ilmu teatang bank syariah atau ekonomi syariah, dia bagaikan orang yang berjalan tanpa arah. Sampai saat ini masih jarang praktisi perbankan syariah yang memiliki kedua hal tersebut. Sehingga bank syariah harus mulai berfikir untuk mengembangkan SDM yang dimiliki agar seimbang kemampuannya dalam ilmu bank syariah dan secara psikologis juga mampu membangun semangat keislaman dalam dirinya.

Pengembangan

kualitas

infrastruktur meliputi penyediaan fasilitas-fasilitas yang akan memberikan pelayanan kepada konsumen dalam mengakses bank syariah secara mudah, murah, dan cepat. Seperti kita ketahui sampai saat ini operasionalisasi bank-bank syariah sebagian besar masih berada di wilayah kota-kota besar, dan belum menjangkau daerah-daerah pedesaan. Begitu juga fasilitas-fasilitas yang disediakan pun masih terbatas, seperti ATM. Sehingga selama ini pelanggan di daerah harus menggunakan ATM bersama jika ingin mengakses produk secara mudah dan cepat. Hanya saja ATM bersama ini akan membebankan biaya kepada konsumen yang menggunakan.

\section{PROFILE UKM DI INDONESIA}

Usaha mikro kecil dan menengah (UMKM) menjadi andalan Indonesia pada saat mengalami krisis ekonomi tahun 1998. Meskipun dikelola dengan sangat sederhana, tetapi pada saat itu mampu memberikan peranan yang besar dalam penanganan krisis. UMKM menjadi tumpuan dan menjadi pilihan banyak sarjana baruyang lulus waktu itu, dan UMKM mampu menggerakkan roda perekonomian yang mengalami kemunduran, serta banyak menolong orang keluar dari situasi pengangguran.

Karakteristik dari usaha mikro biasanya dikelola secara mandiri, dengan modal kecil, fleksibel dan tahan banting.. Kondisi ini yang ditengarai menjadi factor penentu sehingga usaha mikro tidak ikut bankrut akibat adanya krisis. Pengelolaan usaha dilakukan secara sederhana, tanpa menggunakan manajemen yang baik, dan modal yang terbatas, sehingga mereka sering kesulitan mengembangkan usahanya.

Sampai awal tahun 2011, di Indonesia tercatat ada sekitar 520.220 usaha kecil dan usaha mikro yang sudah tidak terhitung. Dari jumlah usaha kecil tersebut, jumlah tenaga kerja yang bisa diserap sekitar 10 juta tenaga kerja. UMKM tumbuh tidak 
Maisaroh \& Ati Sumiati: Tantangan dan Peluang Perbankan Syariah Dalam Pengembangan

sekedar di desa tetapi juga di kotakota besar.

\section{PERAN BANK SYARIAH DALAM PEMBERDAYAAN MASYARAKAT}

Resistensi usaha kecil dan menengah (UKM) dalam menghadapi badai krisis moneter telah membuka mata kita, bahwa eksistensi UKM sebagai unit usaha telah mampu menghantarkan pertumbuhan kembali perekonomian Indonesia. Pada saat badai krisis melanda, banyak perusahaan-perusahaan besar tumbang satu persatu, PHK terjadi di mana-mana, lapangan kerja menjadi begitu sulit didapatkan. Hal ini terjadi karena perusahaan-perusahaan tersebut banyak bergantung pada perbankan konvensional yang mendasarkan prakteknya pada bunga. Berbeda keadaannya dengan UKM, pada masa krisis UKM justru menunjukan geliat usaha meningkat, menciptakan lapangan kerja dan mampu menyerap ribuan tenaga kerja, dan secara mandiri dalam prakteknya tidak bergantung pada perbankan konvensional. Sehingga dari usaha yang berlangsung terus menerus ini akhirnya UKM mampu menggerakkan kembali perekonomian nasional.

Bank syariah sebagai salah satu perbankan di Indonesia memiliki kepentingan untuk membina Meningkatnya jumlah UKM yang ada di Indonesia merupakan peluang yang strategis dalam pencarian pangsa pasar bank syariah. Dan juga ini sejalan dengan tujuan operasional bank syariah untuk ikut mensejahterakan seluruh lapisan masyarakat. Apalagi sampai saat ini operasional UKM masih banyak yang belum tersentuh praktek pembiayaan perbankan, baik perbankan umum maupun perbankan syariah. Hal ini disebabkan oleh beberapa hal, pertama, kadang beberapa UKM merasa bahwa mereka sudah cukup mandiri dengan modal yang mereka miliki sendiri, sehingga mereka tidak membutuhkan jasa perbankan dalam memenuhi kebutuhan modalnya.

Kedua, kadang beberapa UKM terbentur dengan beberapa hal prosedural yang ditetapkan oleh bank penyedia dana, seperti persyaratan $4 \mathrm{C}$ (colateral, capital, capacity, dan character). Ketiga, pada lapisan masyarakat tertentu akses dan informasi produk perbankan sangat minim, sehingga pengetahuan UKM akan jasa perbankan juga menjadi sangat minim pula. Keempat, masih banyaknya praktek bank plecit di pedesaan yang mengedepankan layanan yang praktis membuat banyak UKM lebih memilih altenatif ini, meskipun bunganya sangat tinggi.

$$
\text { Profil UKM pada umumnya }
$$
memiliki permasalahan sebagai berikut, pertama, kelangkaan modal, faktor ini dinilai sebagai faktor yang dimiliki oleh sebagian besar UKM di Indonesia. Rata-rata UKM memulai usahanya dengan modal seadanya, sehingga ketika usahanya mulai berkembang masalah yang pasti muncul adalah berkaitan dengan modal. Apalagi kalau mereka harus menginvestasikan modal untuk pembelian alat-alat produksi, dan lainlain diluar bahan-bahan langsung yang digunakan untuk produksi. Masalah ini akan mudah teratasi kalau mereka 
Maisaroh \& Ati Sumiati: Tantangan dan Peluang Perbankan Syariah Dalam Pengembangan

juga dengan mudah mengakses sumber atau lembaga penyedia dana, seperti perbankan, dan lain-lain. Akan teteapi pada prakteknya usaha untuk mendapatkan modal yang dilakukan oleh UKM menjadi sulit dilakukan. Beberapa faktor yang mempengaruhi kondisi ini lebih dikarenakan adanya kekurangan informasi yang lengkap tentang produk perbankan, dan adanya kendala assesibilitas yang ditetapkan oleh bank.

Permasalahan kedua yang dihadapi oleh UKM adalah akses pemasaran yang minim, akibat dari minimnya pengetahuan mereka tentang pangsa pasar yang ada dan strategi yang harus dilakukan dalam menarik minat pelanggan. Kebanyakan dari UKM ini masih beroperasi dengan cara yang sederhana, seperti pemasaran dilakukan secara person to person, pengemasan yang sederhana, bahkan beberpa produk masih belum memperhatikan unsur higienis, apalagi ramah lingkungan. Mereka jarang berfikir untuk bermain dipasar nasional apalagi regional, mereka akan puas ketika apa yang sudah diproduksi sudah terjual dan tidak merugi. Selain itu ditambah pengetahuan yang minim akan teknologi semakin melengkapi kelemahan mereka dalam proses pemasaran produknya.

Permasalahan ketiga, masalah kurangnya sumber daya manusia yang handal dalam praktek manajemen perusahaannya. Operasi perusahaan biasanya hanya dilakukan dengan manajemen yang sangat sederhana dan dengan kemampuan yang seadanya, sehingga efisiensi dan efektifitas menjadi masalah yang membudaya di tubuh UKM.

Berdasarkan permasalahan di atas, dan adanya peluang pangsa untuk mengembangkan bisnis, maka bank syariah di Indonesia, sesuai dengan fungsinya, harus mampu berperan dalam menghantarkan dan memberdayakan UKM di Indonesia. Pemberdayaan berarti suatu proses pengembangan potensi, kemampuan, dan kapasitas suatu kelompok masyarakat atau komunitas. Dari pengertian ini terlihat bahwa proses pemberdayaan ada transformasi yang seimbang dari kondisi tidak mampu menjadi mampu, dari tidak tahu menjadi tahu. Ini berarti ada proses edukasi dalam rangka peningkatan kualitas.

Seperti dikemukakan di muka dihadapi UKM adalah berkaitan dengan kelengkapan modal, maka bank syariah dalam hal ini harus mampu menangkap peluang, dengan melakukan pembiayaan dengan akad bagi hasil, baik musyarakah maupun mudharabah. Meskipun adanya beberapa permasalahan yang melingkupi seperti yang sudah diungkap di atas (seperti agency problem, dan potensi macet), tetapi bank syariah tetap harus mampu menjadi pelopor untuk melakukan inovasi produk dalam akad pembiayaan model ini.

Kalau kita telaah lebih jauh, sebenarnya ada perbedaan perilaku kebanyakan pelaku UKM dengan perusahaan besar, terutama dalam hal character. Diakui atau tidak, adanya pengalaman yang minim dari pelaku 
Maisaroh \& Ati Sumiati: Tantangan dan Peluang Perbankan Syariah Dalam Pengembangan

UKM, menjadikan mereka melakukan bisnis dengan tingkat kejujuran yang lebih tinggi, hal ini tercermin dari praktek pembiayaan macet perusahaan besar ternyata lebih besar dari UKM, tetapi lebih karena faktor lain, sepeti kesalahan manajemen perbankan sendiri. Seperti kita ketahui banyak sekali perbankan yang menyalurkan dananya tanpa melakukan identifikasi terlebih dahulu terhadap kebutuhan UKM dan memberikan plafon kredit yang melebihi kebutuhan modal UKM. Kondisi ini tentu mendorong ketidakseimbangan operasi UKM, karena besarnya beban bunga yang harus ditanggung, sementara perbankan sendiri tidak mampu melakukan kontrol dalam setiap operasi perusahaan, apalagi berpartisipasi dalam penentuan kebijakan strategis.

Berkaitan dengan permasalahan di atas, ada beberapa alternatif solusi agar perbankan tetap dapat melakukan operasi pembiayaan dengan akad musyarakah dan mudharabah, dan dapat menjalankan misinya untuk mensejahterahkan masyarakat, tanpa harus mengalami masalah kredit macet. Alternatif solusi yang ditawarkan adalah program pemberdayaan dengan pola pendampingan kepada kelompok UKM sasaran, baik melalui pendekatan individu maupun kelompok.

Pemberdayaan dengan pola pendampingan berarti bahwa pihak bank baik secara langsung maupun tidak langsung akan menjadi mitra UKM, dan selain sebagai penyelia dana, dia akan berperan sebagai motivator, dinamisator, dan katalisator bagi pengembangan UKM kedepan. Pendampingan secara langsung berarti perbankan akan menjadi pihak pendamping secara langsung bagi operasional perusahaan. Tugas ini bisa dilakukan oleh karyawan di bawah departemen pemasaran yang secara langsung berhubungan dengan masyarakat. Pendampingan secara tidak langsung berarti pihak bank akan menunjuk suatu lembaga mitra, seperti konsultan, dan lain-lain, untuk menjadi wakil bank, untuk mendampingi UKM dalam proses pengembangan usahanya.

Untuk mengoptimalkan perkembangan UKM, dalam proses pemberdayaan dan pendampingan ini pihak bank harus bertumpu pada tiga konsep dasar:

1. Konsep Silaturahmi, yang merupakan konsep dimana ada usaha untuk melakukan kontak secara langsung secara intensif antara pihak bank dan UKM. Dengan konsep ini memungkinkan tercipta proses transfer informasi antar kedua belah pihak akan kebutuhan UKM disatu sisi dan kepentingan bank disisi lain, yang menjadi modal awal untuk membangun kerja sama.

2. Konsep kebersamaan, yang merupakan proses untuk menciptakan rasa saling ketergantungan, membangun kepercayaan dan tanggung jawab, yang merupakan aktualisasi dari bentuk kerja sama atau kemitraan. 
3. Konsep kemanusiaan, yang merupakan proses penjabaran misi bank syariah untuk mensejahterakan umat melalui upaya pengembangan UKM dan pemerataan kekayaan, yang terealisasi dalam perubahan struktur kekayaan masyarakat dari tidak mampu menjadi mampu.

Dengan konsep ini akan mampu menciptakan sinergi antara bank syariah dan UKM dalam mencapai tujuan bersama. Di samping itu secara logika UKM sebagai pihak pembeli produk bank akan merasakan secara nyata produk yang dibeli, karena secara berkala dia akan mendapat layanan berupa pendampingan dari bank syariah. Keadaan ini akan menjadi keunggulan bagi bank syariah, karena seperti kita ketahui sebagai perusahaan jasa, maka salah satu kelemahannya adalah akan sulit bagi bank untuk mewujudkan karakteristik intangible yang melekat dalam produknya ke dalam tangibilitas produknya untuk konsumen. Dengan konsep tadi maka secara tidak langsung bank sudah mampu menghapuskan kelemahannya.

Dengan bertumpu pada tiga konsep pemberdayaan ini, secara berkala bank atau lembaga yang ditunjuk bank untuk mendampingi UKM akan mengunjungi UKM dan secara aktif berperan dalam melakukan proses identifikasi kebutuhan UKM, identifikasi masalahmasalah yang dihadapi UKM, dan memberikan arahan dan pandangan tentang kebijakan yang akan diambil pemilik UKM dalam operasional kesehariannya. Pada tataran praktis bank syariah selain memberikan bantuan modal (setelah sebelumnya melakukan identiikasi kebutuhan modal perusahaan) juga akan membantu memberikan pelatihanpelatihan yang memungkinkan peningkatan manajemen operasional perusahaan, memberikan informasi akses pemasaran, pembinaan SDM, dan lain-lain aktifas yang dapat memecahkan masalah yang selama ini dihadapi dan mendukung pengembangan UKM. Jadi disini peran pendampingan dan pemberdayaan ini tidak sekedar memberikan dana saja, tapi yang lebih penting adalah membantu UKM untuk menentukan kebutuhan dananya dan mendampingi proses pemanfaatan dana tersebut. Bahkan dalam beberapa kasus ada beberapa UKM yang tidak perlu tambahan modal. Kalau sudah begitu maka keuntungan bank tidak lagi pada laba riil yang dihitung secara matematis, tapi lebih pada aktualisasi konsep pemasaran sosial, untuk memberikan kemanfaatan sebanyakbanyaknya untuk masyarakat, dan ini dampak labanya baru bisa diukur pada jangka panjang.

Kalau dilihat dari sistem operasionalnya, maka proses pendampingan ini akan membutuhkan biaya yang besar, apalagi dengan laba riil yang masih belum jelas. Pada jangka pendek ada beberapa manfaat yang bisa diperoleh bank dalam proses pendampingan ini, pertama, pusat informasi dan promosi produk-produk bank syariah. Kedua, untuk mengidentifikasikan kebutuhan UKM. 
Maisaroh \& Ati Sumiati: Tantangan dan Peluang Perbankan Syariah Dalam Pengembangan

Ketiga, untuk menghindari agency problem.

Seperti kita ketahui bahwa kebanyakan operasional bank syariah sampai saat ini masih terbatas pada tingkat kabupaten, sehingga banyak kelompok masyarakat yang belum tersentuh produk bank syariah. Bahkan yang lebih parah lagi mereka tidak tahu apa saja produk bank syariah tersebut dan bingung membedakan operasional bank syariah dan bank konvensional. Melihat kondidi ini wajar kalau banyak UKM yang masih belum berhubungan dengan bank syariah. Dengan adanya pola pendampingan maka bisa dijadikan sebagai pusat informasi dan ajang promosi setiap produk-produk yang ditawarkan bank syariah.

Salah satu kelemahan UKM dalam operasionalnya sering tidak bisa menentukan kebutuhan modalnya secara tepat. Sehingga ketika mereka ditawari bantuan modal, mereka akan mengambil plafon yang sebesarbesarnya. Padahal mereka tidak tahu bahwa dengan meminjam modal dengan nominal yang besar, mereka juga punya kewajiban untuk memberikan bagi hasil sesuai dengan yang disepakati. Apabila pinjaman yang besar ini dialokasikan semua untuk operasional dan dibarengi dengan kinerja yang baik, maka dengan didukung tersedianya pangsa pasar yang memadai, kondisi ini tidak akan jadi masalah. Akan tetapi ratarata kondisinya berbeda. UKM yang mendapat modal dengan jumlah besar tidak tahu harus mengalokasikan dananya kemana, sehingga larinya untuk konsumsi pribadi, dan bukan untuk memperluas usaha. Dengan adanya pola pendampingan maka pihak bank syariah akan membantu mengidentifikasikan kebutuhan dana perusahaan. Dan setelah dana dicairkan bank pun akan mendampingi UKM untuk mengatur alokasi dana tersebut untuk operasional perusahaan. Selain itu dengan pendampingan ini juga memungkinkan bank untuk memberikan bantuan secara bertahap, dan mengevaluasi pertahapnya untuk menentukan jumlah modal yang akan diberikan pada tahap berikutnya. Pada konteks bank syariah, konsep ini bisa juga dipakai untuk menerapkan sistem pembiayaan yang diberikan. Misalnya pada tahap awal pembiayaannya dilakukan dengan akad murabahah, baru ditingkatkan pada akad musyarakah, dan terakhir tahap mudharabah.

Terakhir dengan adanya pola pendampingan, secara intensif bank syariah akan menjadi moivator, dinamisator, dan katalisator bagi pengembangan UKM sampai mereka mapan dan mandiri untuk dilepas. Peran ini memungkinkan bank syariah untuk mendampingi, memberikan arahan kebijakan, bahkan proses monitoring sekalipun bisa mereka lakukan. Selain itu dengan pola ini bank syariah akan mampu melihat character dari masing-masing UKM yang menjadi modal dasar penilaian pembiayaan. Dengan proses ini maka agency problem sudah dieliminasi kemunculannya, maka kekhawatiran bank syariah untuk melakukan pembiayaan dengan akad musyarakah 
Maisaroh \& Ati Sumiati: Tantangan dan Peluang Perbankan Syariah Dalam Pengembangan

dan mudharabah otomatis akan hilang.

Pada jangka panjang proses pendampingan ini akan memantapkan eksistensi bank syariah terutama untuk mewujudkan kiprah mereka dalam konsep pemasaran sosial. Bukankah pada tingkat yang paling tinggi misi bisnis sebuah usaha itu harus mampu mewujudkan harmonisasi hubungan antar sesama mahluk ciptaan Tuhan, tidak merusak sumber daya alam yang ada, menghindari kemubaziran dan perilaku lain yang dapat mengakibatkan kemunduran dan merusak moral dan akhlak masyarakat? Kondisi ini hanya bisa dilakukan ketika perusahaan sudah mampu mengaplikasikan konsep pemasaran sosial dalam operasional kesehariannya.

Sementara di sisi lain sebagai perusahaan, meskipun dengan pola pendampingan ini aktifitas perusahaan akan diketahui dan dimonitor perkembangannya, tetapi monitoring di sini tidak sekedar monitoring untuk mencari kesalahan dan kelemahan perusahaan, tetapi lebih dari itu ada dampak yang positif bagi perkembangan dan kemajuan perusahaan. Karena dalam proses pendampingan ini mereka akan mendapat pembelajaran dalam praktek manajemen operasional perusahaan dan pembelajaran untuk mengatasi permasalahan yang dihadapi melalui training, informasi akses pemasaran, dan lain-lain penyelesaian yang selama ini biasanya menjadi halangan untuk kemajuan perusahaan.

\section{STRATEGI PENDUKUNG}

Seperti kita ketahui bahwa meskipun pangsa UKM masih banyak yang belum tergarap, tetapi dengan adanya perkembangan pertumbuhan bank syariah, maka otomatis persaingan akan meningkat. Apalagi di Indonesia tidak ada aturan yang membatasi berapa maksimal jumlah perbankan yang boleh beroperasi di Indonesia. Sehingga dalam kondisi ini persaingan perbankan hanya diatur oleh mekanisme pasar (market driven), yang berarti eksistensi sebuah perbankan akan ditentukan oleh mekanisme yang berjalan di pasar. Logikanya perbankan yang akan bertahan di pasar adalah perbankan yang produk-produknya diminati konsumen dan mampu menarik pelanggan sebanyak-banyaknya. Oleh karena itu masing-masing lembaga akan berusaha menarik pelanggan UKM sebanyak-banyaknya dengan berbagai cara mengingat potensi yang besar dari UKM ini. Persaingan ini tidak dilarang dalam praktek perbankan, asal dalam persaingan ini tetap mengedepankan praktek yang sehat dan tetap dalam koridor sistem syariah Islam.

Oleh karena itu masing-masing bank syariah harus mempunyai strategi yang handal untuk menarik pelanggan UKM. Inovasi produk dicatat sebagai strategi pertama dan utama yang diusulkan penulis. Karena strategi ini dinilai merupakan strategi yang ampuh dan efektif untuk dapat menarik nasabah baru dan mempertahankan pelanggan. Dalam melakukan inovasi produk ini bank syariah harus mengedankan keunikan 
Maisaroh \& Ati Sumiati: Tantangan dan Peluang Perbankan Syariah Dalam Pengembangan

produk (uniqueness) dan perbedaan khas dari produk lainnya (differnt). Beberapa cara bisa dilakukan, misalnya, dengan menonjolkan pelayanan prima, kemudahan, berbasis teknologi, dan lain-lain produk yang bisa menarik pelanggan. Akan tetapi harus diingat, jangan sampai inovasi produk yang dilakukan oleh bank syariah justru bertentangan dengan konsep syariah.

Strategi kedua, dengan melakukan perluasan jaringan sampai tingkat kecamatan, bahkan kalau memungkinkan sampai pada tingkat kelurahan. Sehingga konsumen dengan mudah dapat menjangkau dan mengakses layanan perbankan yang bersangkutan. Ingat kemudahan akses perbankan menjadi faktor utama bagi konsumen untuk memutuskan dengan bank mana dia akan bertransaksi.

Peningkatan kualitas sumber daya manusia, untuk memberikan pelayan yang prima kepada pelanggan. Karena perbankan merupakan perusahaan jasa, maka pelayanan yang diberikan menjadi faktor yang melekat dalam produknya. Oleh karena itu kualitas produk perbankan akan ditentukan oleh sejauh mana kualitas pelayanan yang diberikan kepada pelanggan. Dan ini yang menentukan adalah sumber daya manusia yang ada dimiliki perbankan. Apalagi dalam proses percepatan pertumbuhan perbankan saat ini, maka SDM yang handal menjadi faktor penentu keberhasilan perusahaan.

Berdasarkan bukti yang ada, faktor-faktor di atas menjadi faktor penentu keberhasilan perbankan dalam menarik konsumen dan mempetahankan pelanggan. Oleh karena itu perbankan yang ingin bertahan dalam persaingan ini harus mampu membuat strategi tersebut secara sinergis dan berkesinambungan.

\section{PENUTUP}

Fungsi bank syariah adalah menjadi lembaga perantara (intermediasi) dari pihak yang memiliki kelebihan dana kepada pihak yang kekurangan dana, dalam rangka mewujudkan kesejahteraan masyarakat (sosial welfare), dengan menggunakan konsep syariah Islam.

Dalam konteks pengembangan UKM, bank syariah mempunyai tanggung jawab untuk berperan serta dalam mengembangkan dan mengoptimalkan kemampuan UKM, melalui mekanisme kemitraan dengan akad musyarakah dan mudharabah, sehingga memungkinkan terwujudnya pemerataan kekayaan dan mengurangi budaya konsumtif yang sering terjadi di masyarakat.

Dengan dibarengi upaya peningkatan kualitas operasional dan pelayanan yang diberikan, dapat meningkatkan resistensinya dalam persaingan. Selain itu dengan melakukan inovasi yang berkesinambungan dan terus menerus maka perbankan dapat mempertahanka loyalitas pelanggan. Dan dengan komitmen yang tinggi untuk memperhatikan UKM, maka usaha yang dilakukan perbankan dalam memberdayakan dan memandirikan UKM benar-benar tercapai, dan kesejahteraan 
masyarakat seperti cita-cita awalnya dapat terwujud.

Bukankan Allah dalam Al Qur'an

Surat Ar Ra.du: 11 secara jelas sudah menjelaskan bahwa nasib suatu bangsa tidak akan berubah tanpa mereka sendiri yang merubahnya. Di sini terkandung makna bahwa perubahan itu peru usaha untuk berinisiatif dan bukan ketergantungan. Dengan usaha keras kita dan tanpa putus asa, semoga cita-cita untuk mendirikan UKM sebagai faktor pendorong terciptanya kesejahteraan umat akan terwujud dimasa datang.

\section{DAFTAR PUSTAKA}

Alwi S., 1993. Zakat dan Pemberdayaan Ekonomi Umat, Buchari A., 2009. Islamic Economic Ekonomi Syariah Bukan Opsi Tetapi Solusi, Bumi Aksara Jakarta,

Certo J.S., Peter P., 1990. Strategic Management A Focus on Process, Mc. Grow Hill,

Dahlan Siamat, 2007. Manajemen Lembaga Keuangan, Jakarta: FE UI,

Fredericks Miskin, 2007. The Economics of Money, Banking and Financial Markets, New York:

Pearson,

Hidayat M., 2010. An Introducing to the sharia Economic - Pengantar Ekonomi Syariah, Zikrul Hakim Jakarta,

Kasmir, 2007. Bank dan Lembaga

Keuangan, Jakarta: PT Raja

Grafindo Persada,
Sigit \& Totok, 2007. Bank dan Lembaga Keuangan Lainnya, Jakarta: Salemba Empat. 